\title{
Improving The Students' Reading Comprehension in Narrative Text by Using SQ3R
}

\author{
Ahmad Heriyanto, Siswantoro, Teguh Sarosa
}

\author{
English Education Department \\ Teacher Training and Education Faculty \\ Sebelas Maret University of Surakarta
}

Email: ahmadheriyanto09@yahoo.com

\begin{abstract}
The objectives of this classroom action research are to identify: (1) whether SQ3R method can improve the students ${ }^{\text {ee }}$ reading comprehension; (2) the classroom situation of using SQ3R method in teaching and learning process. The research data were collected by using techniques of interview, observation, questionnaire and tests. The qualitative data were analyzed by assembling the data, coding the data, comparing the data, building interpretations, and reporting the outcomes. The quantitative data were analyzed by comparing the mean score of pre-test and post-test. The research findings show that SQ3R method can improve the studentse reading comprehension and the classroom situation. It can improve the students ${ }^{\text {ee }}$ reading comprehension in five aspects including finding main idea, explicit and implicit information, reference of pronoun, and identifying the meaning of word. The classroom situation shows that the students are more active in teaching and learning process. They pay more attention to the teachers ${ }^{\text {ee }}$ explanation; look conducive and enthusiastic in reading class.
\end{abstract}

Keywords: $S Q 3 R$, reading comprehension, classroom situation

\section{INTRODUCTION}

In Indonesia, the ability to read texts in English is very important for students as a bridge to understand the text books they need. By reading, they can enrich their insight and knowledge. Actually, reading cannot be separated from comprehension. Without comprehending the text, the reader will not understand the message in the text.

The aim of reading activity is to understand meaning (a message) of a text.

Learners must have an ability to comprehend both spoken and written texts adequately. Those who have good reading competence will be able to understand them easily and it can support the other skills. That is the reason why having reading competence is very important for learners.

According to Grellet (1985: 8), reading is an active skill that constantly involves guessing, predicting, checking, and asking oneself questions. It means that a reader not only understands a printed material but also needs background knowledge on the field of the text.

Other experts, Grabe and Stoller (2011: 3 ) define reading is ability to draw meaning from printed page and interpret this information appropriately. Reading is not only making sense of written or printed symbols, but also how to interpret the information in the text appropriately.

$$
\text { Meanwhile, according to }
$$

Silberstein (1995: 12) reading is a complex 
information processing skill in which the reader interacts with the text in order to (re)create meaningful discourse. It means that reading is an essential skill. Student needs an ability to understand and to comprehend written material.

Based on the observation in one of SMA MUHAMMADIYAH in Karanganyar, the researcher found the students $^{\text {ee }}$ problems in reading comprehension and classroom situation. The problems above are caused by some reasons. The researcher found out those reason from the questionnaire, the interview, pre-observation, and the pre-test result. First, the problem indicators appeared from the students ${ }^{\text {ee }}$ competence in reading comprehension. The problems of reading which students faced are that they found the difficulty in finding the main idea. Then, they also got the difficulties in finding explicit and implicit information. Next, they got the difficulties in finding reference of pronoun. The last, they got it difficult to identify the meaning of words of the text.

Second, based on the classroom situation, it can be seen that: (1) the students tend to lose their focuses during the lesson, (2) the students make the class noisy, so situation in the class became noisy and uncomfortable to study, (3) the students looked passive in lessons, they rarely delivered their ideas, if their teacher asked them a question, they would not answer the question spontaneously but they waited their teacher to point them out,

(4) the students were less enthusiastic to read the text.

There are many techniques that can be used to improve students reading comprehension. In order to overcome those problems, the researcher proposes SQ3R method for developing the students ${ }^{\text {ee }}$ reading comprehension. SQ3R (Survey, Question, Read, Recite, Review) is a comprehension strategy that helps students think about the text that they are reading. SQ3R is a method introduced by Francis P. Robinson in 1941. With a survey at the beginning, it aroused the curiosity of the students to the material that will be learned, so it can enhance their motivation in learning. Next question and read, the students are given the opportunity to ask questions and try to find answers by reading activities. Thus it can encourage them to think critically and have an active and a meaningful learning. Recite and review are the post reading activity of part in SQ3R method. They help the readers summarize and organize ideas so they can memorize it longer.

From the problems above, the researcher is interested in implementing SQ3R method to overcome the students ${ }^{\text {ee }}$ problems in reading comprehension and classroom situation.

\section{RESEARCH METHODS}

This research was conducted in one of SMA MUHAMMADIYAH in Karanganyar. The subject of the research was the eleventh grade students. The class was XI IA3. It consisted of 4 boys and 16 girls. The researcher used an action research on the basic of the model of action research developed by Kemmis and Mc Taggart in Burns (1999: 33). They explain that action research occurs through a dynamic and complementary process, which consists of four essential steps:

planning, action, observation and reflection.

The four steps at the model can be expanded into six steps which include in the procedure of action research. The procedures are identifying the problem, 
planning the action, implementing the action, observing the action, reflecting the action, and revising the plan.

In this research, the data were collected by using techniques of interview, observation, questionnaire, and tests (pretest and post-test). The researcher used the unstructured or informal interview where the interviewer and interviewee were engaged in free-flowing conversational process based on the issues and topics of the research study. The researcher observed the teaching learning process in class XI IA3 to know how are the classroom atmosphere and the students $^{\text {ee }}$ activities during the teaching learning process. The researcher gave questionnaire to the students when the researcher did pre-research to know the studentse learning style, class condition and the teacher"s teaching style. The researcher tested the students by using written test that consisted of pre-test, post-test 1 and post test 2 . The result of the test was analyzed

to know the students ${ }^{\text {ee }}$ reading comprehension.

The qualitative data were analyzed by assembling the data, coding the data, comparing the data, building interpretations, and reporting the outcomes. The quantitative data were analyzed by comparing the students ${ }^{\text {ee }}$ mean score of pre-test, post-test 1 , and post-test 2.

\section{RESEARCH FINDINGS AND DISCUSSIONS}

Based on the observation, the researcher found some problems dealing with reading at the eleventh grade students. Their problems in reading comprehension were indicated from students ${ }^{\text {ee }}$ reading and classroom situation. Based on the pre-test conducted, the researcher found that the students had low reading competence. They should have at least 75.00 as their minimum score for listening, speaking, reading and writing. It is very different from the fact taken from the results of pre-test conducted by the researcher on October $11^{\text {st }}$ 2013. The result of pre test showed that studentse mean score was 63 . It means that students ${ }^{\text {ee }}$ score did not reach the minimal score.

The students only got 63 for the mean of students ${ }^{\text {ee }}$ reading scores. The students ${ }^{\text {ee }}$ score of pre-test would be compared with the post-test in cycle 1 and cycle 2 to know the students ${ }^{\text {ee }}$ improvement

in reading comprehension. After conducting the pre-test, the researcher held the first post-test. The researcher got improvement in students ${ }^{\text {ee }}$ result of firstpost test. The mean score of first post-test was 68.

The improvements of the students ${ }^{\text {ee }}$ reading comprehension balanced with the improvement of classroom situation during the teaching learning process. In the first meeting, the students were still less enthusiastic to read the text, only few students from each group were enthusiastic to read, while others had fun playing mobile phones and some others were just silent. Besides, not all of the students were active in the review step because they still looked passive when asked about moral value of the text. But, in the next meeting, the students showed their activeness in the teaching learning process. They tried to answered questions simultaneously and the classroom situation was more manageable. Then, the classroom situation showed the positive result in the next meetings because the students were calmer than yesterday. It was because other students were busy checking their answers again. 
After the implementation of cycle 1, the researcher also found the improvements of the classroom situation in the teaching learning process. The improvement of classroom situation can be seen in table 1 .

\section{Table 1. The Improvement of Classroom Situation in the End of Cycle 1}

\begin{tabular}{ll}
\hline \multicolumn{1}{c}{ Pre-Research } & \multicolumn{1}{c}{ After the action } \\
\hline $\begin{array}{l}\text { 1. The students tended to lose their focuses } \\
\text { during the lesson }\end{array}$ & $\begin{array}{l}\text { 1. Most of the students could respond and pay } \\
\text { more attention to the teachers explanation } \\
\text { on the involvement of teaching activities }\end{array}$ \\
$\begin{array}{l}\text { 2. The class atmosphere was calmer, but was } \\
\text { situation in class became noisy and } \\
\text { uncomfortable to study }\end{array}$ \\
$\begin{array}{l}\text { 3. The students looked passive in lessons, } \\
\text { they rarely delivered their ideas, if their } \\
\text { teacher asked them a question, they would } \\
\text { not answer the question spontaneously but } \\
\text { they waited their teacher to point them out } \\
\text { The students were less enthusiastic to read } \\
\text { the text }\end{array}$ & $\begin{array}{l}\text { Most of the students were more active in } \\
\text { the teaching learning process. They began } \\
\text { questions }\end{array}$ \\
\end{tabular}

After the end of cycle 1, the researcher still found some problems. First, the problems related with the students ${ }^{\text {ee }}$ reading comprehension. Most of them could not conclude what the content of the text. Then, sometimes they still found it hard to determine what the word refers to. Second, the problems related with classroom situation were some students still asked their friends and the researcher about English vocabulary, so it made the classroom situation become a little bit noisy.

Based on the problems found after cycle 1 , the researcher made strategies in the next cycle to avoid the problem. In the students $^{\text {ee }}$ reading comprehension, the researcher would focus on the SQ3R method steps called survey. The researcher also would remind the students about the time allotment, so they could focus on their reading. In the classroom situation, the teacher would guide the students who had problems in vocabulary. He would ask the students to bring the dictionary or use the teacheres dictionary, so they couldn ${ }^{\text {eet }}$ ask their friends about English vocabulary and made the situation more manageable and conducive.

There were some positive results reflected in the second cycle. The result of the second post-test showed the studentse progress in reading comprehension. The mean score of second post test is 75.8. It was better than the mean of post-test 1 . It was 68. It was also higher than the KKM of English lesson (75).

The result of second post-test also showed the improvement of reading comprehension in finding main idea, finding explicit and implicit information, finding reference of pronoun, and identifying the meaning of word. In finding main idea they showed the positive result. It happened because they could conclude what the content of the text is; it means that the students could understand the whole text.

In finding explicit information, the students knew the meaning of the words 
contained in the text and could explain what they got from the text. This happened because the students not only read the text word by word. Then, in finding implicit information, the students could understand the content of the text. Thus, they could conclude what they got or benefit from the text. In finding the reference of pronoun, the students found it easy to determine what the word refers to. Last, the students were better in identifying new vocabulary.

Besides, it presented the example of the score from their reading, the sample of the students score were taken from different level of intelligence. The improvement was summarized below.

Table 2. The Improvement of Students" Score

\begin{tabular}{lllll}
\hline & Pre-test & Post-test 1 & Post-test 2 & Mean Score \\
\hline $\begin{array}{l}\text { Student } \\
\begin{array}{l}\text { (RP) } \\
\text { Student }\end{array}\end{array}$ & A 76 & 86 & 88 & 83.3 \\
$\begin{array}{l}\text { (UA) } \\
\begin{array}{l}\text { Student } \\
\text { (SAB) }\end{array}\end{array}$ & C 52 & 74 & 78 & 72 \\
\hline
\end{tabular}

Student A was indeed known as the smart students. She always paid attention to the lesson in class. She was enthusiastic and did not make noise in reading class. She could understand the lesson quickly, if she found difficulties she always asked the researcher.

Student B was considered in the average level. Actually, she had good reading comprehension. Nevertheless, she sometimes was not interested in the lesson. Although she knew the answers of given questions, sometimes she were lazy to answer. Furthermore, she easily got bored and tended to make noise in the class by playing hand phone or chatting with her friends. However, she became more active in every meeting.
Student $\mathrm{C}$ is included in the lower level. Actually, he did not like reading in the class but he preferred to do something with his hand phone. He had difficulties in finding implicit information of text, but the researcher tried to help him and concerned on his difficulties. Finally, he could get better score in two cycles. The result of the test showed the improvement of his reading comprehension. Based on the result of the tests, it could be seen that there was improvement of the score between pre-test, post test 1 , and post test 2 .

Moreover, in the cycle 2, the classroom situation also shows the positive result. The improvement of the classroom climate is shown in table below.

Table 3. The Improvement of Classroom Situation in the End of Cycle 2 After The Action of Cycle 1 After The Action of Cycle 2

\begin{tabular}{ll}
\hline \multicolumn{1}{c}{ After The Action of Cycle 1 } & \multicolumn{1}{c}{ After The Action of Cycle 2} \\
\hline $\begin{array}{l}\text { 1. Most of the students could respond and pay } \\
\text { more attention to the teacherse explanation } \\
\text { on the involvement of teaching activities }\end{array}$ & $\begin{array}{l}\text { 1. All of the students paid more attention to the } \\
\text { teachers explanation and focus on the } \\
\text { involvement of teaching activities }\end{array}$ \\
$\begin{array}{ll}\text { 2. The class atmosphere was calmer, but still } \\
\text { little bit noisy }\end{array}$ & $\begin{array}{l}\text { 2. The class atmosphere looked conducive } \\
\text { 3. All students looked active and cooperative by } \\
\text { collaborate with the researcher. }\end{array}$ \\
\hline
\end{tabular}


teaching learning process. They began to cooperate with researcher by answered questions

4. Most of the students were looked enthusiastic to read the text
4. The students read the text with enthusiasm
After conducting cycle 2, the researcher noted that the teaching learning process could run well. The students participated in the teaching learning process by giving attention and following the teacheres explanation without doing their own business. Then, they were active in answering the teacher ${ }^{\text {es }} \mathrm{s}$ questions, doing the exercise, and giving question if they get difficulties. The class atmosphere also looked conducive. Next, they looked enthusiastic to read the text.

The use of SQ3R method can improve the students ${ }^{\text {ee }}$ reading comprehension in reading narrative text. The students ${ }^{\text {ee }}$ reading comprehension increased after the implementation of SQ3R method. Based on the observation that was held, the researcher found that the students had difficulties in reading. They were classified into two major problems. The first problem deals with the students ${ }^{\text {ee }}$ language skill and the second problem deals with the classroom situation. The problems that were faced by the students in reading include: the students got difficulties to find the main idea of text, find explicit and implicit information of text, find reference of pronoun based on the text, and identify the meaning of words of the text. These problems were also caused by the teaching technique that was used by the teacher. Based on the result of pre-research above, the researcher implemented a SQ3R method to solve the students $^{\text {ee }}$ problems in reading narrative text.
The improvement of students ${ }^{\text {ee }}$ reading comprehension can be seen from the result of students ${ }^{\text {ee }}$ post test. The mean of pre test score is 63 , it improves to 68 in post test 1 , and it increases up to 75.8 in final post test. The result proves that teaching reading using SQ3R method can improve students ${ }^{\text {ee }}$ reading comprehension. By using SQ3R method, the students get new atmosphere in reading a narrative text and it also improves the students ${ }^{\text {ee }}$ reading comprehension. The improvement of students ${ }^{\text {ee }}$ reading comprehension involves some indicators of reading such as finding main idea, finding explicit and implicit information, finding the reference of pronoun, and identifying the meaning of word. Besides, the use of SQ3R method can also build positive classroom situation during teaching learning process.

\section{CONCLUSIONS AND SUGGESTIONS}

Based on the research findings, the researcher drew some conclusion as follows; SQ3R could improve the students $^{\text {ee }}$ reading comprehension. It is supported by the results of the test scores and the coverage problem indicators. It could be seen from the mean score of pretest 63, it improved to 68 in first post-test, and it increased up to 75.8 in second posttest. The result of post-questionnaire showed that $85 \%$ of students assumed that teacher used new method and more interesting. Then, $70 \%$ of students agreed

that SQ3R method was important to understand the text. Next, $75 \%$ of students agreed that SQ3R method is easier for the 
students to find detail information on the text, and $80 \%$ of students also agreed that they focused more by using SQ3R method.

In fact, SQ3R can make the students become active in teaching and learning process. The students pay more attention to the teachers ${ }^{\text {ee }}$ explanation and focus on the involvement of teaching activities. Moreover, SQ3R can create conducive atmosphere in the classroom. The students read the text with enthusiasm. Last, the students looked active and cooperative by collaborate with the researcher in the teaching and learning process.

It is suggested for the English teachers to make a good planning for carrying out a good English class using SQ3R. Giving suitable material will be effective to enhance their enthusiastic in exploring the background knowledge. The teacher should deliver the material to the students clearly and teaching the students how to understand the text. Teachers should involve or collaborate with the students during the teaching learning process. The teachers have to develop a good atmosphere in the class, so that the students learn at ease and comfortably in their class. Reward is sometimes needed to motivate the students to be more active during the lesson.

The students should be aware about the importance of reading. To improve their reading comprehension, all the students have to practice reading as much as possible because reading is a skill gained by practicing. They should pay attention to the teacherse explanation, and completing the task given by the teacher. Therefore, the students should be more active and enthusiastic during the reading class. The students have to be patient and through in using SQ3R method in reading text with different genre. They can learn
English not only in the class, but also everywhere out of the class.

The school should support the teachers to always learn about how to teach well. Teachers need many references to conduct better teaching. By providing reference books or sending them to workshop or seminar, teachers ${ }^{\text {ec }}$ knowledge of how to create active and effective class will be enhanced. The school also has to provide the good facilities to support the teaching and learning process. They are needed to support the teaching and learning process with preparing LCD and source of electric in each class. It also makes the teachers have opportunity to express their new ideas and show their best ability in improving the language skill especially for reading.

This research is about improving the students $^{\text {ee }}$ reading comprehension by using SQ3R. The findings in this research can be used as reference for other researchers who want to conduct the next research. Hopefully, the research can give an alternative in enhancing classroom action research in reading comprehension. It is suggested that before conducting research, who find as many as possible books and other similar researches to complete the reference of the problems they are going to deal with.

\section{BIBLIOGRAPHY}

Aebersold, Jo Ann. Field, Mary Lee. (1997). From Reader to Reading Teacher: Issues and Strategies for Second Language Classrooms. Cambridge Cambridge University Press

Barkley, Elizabeth F., Cross, K.Patricia., \& Major, Claire Howell. (2005). CollaborativeLearning 
Techniques. San Fransisco, CA: Jossey-Bass.

Brown, H. Douglas. (2004). Language Assessment : Principles and Classroom Practices. New York : Longman.

Burns, Anne. (1999). Collaborative Action Research for English Language Teachers. Cambridge: Cambridge University Press.

Grabe, William. Stoller Fredricka L. (2011). Teaching and Researching Reading Second Edition. London: Longman.

Grellet, Francoise. (1985). Developing Reading Skill A Practical Guide to Reading Comprehension Exercises. Cambridge: Cambridge University Press.

Harmer, Jeremy. (1998). How to Teach English: An Introduction to the Practice of English Language Teaching. Edinburgh: Longman.

Hornby, A S. (1995). Oxford Advanced Learner"s Dictionary. Oxford: Oxford University Press.

Kennedy, Eddie C. (1981). Methods in Teaching Developmental Reading Second Edition.
Englewood: F. E. Peacock Publishers, Inc.

Pardiyono. (2007). Pasti Bisa! Teaching Genre-Based Writing. Yogyakarta: Andi Offset.

Robinson, Francis P. (1941). Effective Study. New York: Harper \& Brothers Publishers.

Silberstein, Sandra. (1994). Techniques and Resources in Teaching Reading. Oxford: Oxford University Press.

Simanjuntak, Edithia Gloria. (1988). Developing Reading Skills For EFL Students. Jakarta: Departemen Pendidikan dan Kebudayaan

Ur, Penny. (1996). A Course in Language Teaching. New York: Cambridge University Press.

Wallace, Michael J. (1998). Action Research for Language Teachers.London: Cambridge University Press.

Williams, Eddie. (1996). Reading in the Language Classroom. London: Macmillan Publishers Ltd. 